\title{
Multilingualism remixed: Sampling, braggadocio and the stylisation of local voice
}

\author{
Quentin Williams \\ University of the Western Cape, Linguistics Department, Centre for Multilingualism and Diversities Research, \\ Private Bag X17, Bellville 7535, South Africa \\ E-mail: qwilliams@uwc.ac.za \\ Christopher Stroud \\ University of the Western Cape, Linguistics Department, Centre for Multilingualism and Diversities Research, \\ Private Bag X17, Bellville 7535, South Africa | Centre for Research on Bilingualism, Stockholm University, SE- \\ 10691 Stockholm \\ E-mail: cstroud@uwc.ac.za; christopher.stroud@biling.su.se
}

\begin{abstract}
Among the many challenges posed by contexts of social transformation and extensive mobility is the question of how multilingual voice may carry across media, modalities and context. In this paper, we suggest that one approach to this complex problem may be to look at multilingual voice from a sociolinguistic perspective of performance. Our focus here is thus on how marginalised voices on the periphery of Cape Town become mainstreamed within the city's hip-hop community. Specifically, we ask how emcees sample local varieties of language, texts and registers to stage their particular stylisation of voice. By way of conclusion, we make brief recommendations with respect to the study of multilingualism in South Africa and how the stylisation of local voices in Cape Town hip-hop could inform studies on multilingual policy and planning.
\end{abstract}

Key words: multilingualism, remixing, stylised voice, sampling, hip-hop

\section{Introduction}

Among the many challenges for young multilingual speakers posed by contexts of social transformation and extensive mobility is the question of how multilingual voice may carry across media, modalities and context. We have argued elsewhere (cf. Williams and Stroud $2010,2013)$ that in order to understand the work that multilingualism does in facilitating or constraining speakers' voice and participation, we need to look outside of more conventional political contexts and consider multilingualism across a variety of practices and spaces, exploring what it means to stylise marginalised language varieties and registers "in the nooks and crannies of everyday life outside of institutionalized contexts" (Besnier 2009). 
Since the inception of hip-hop, scholars have studied how rap performances by young multilingual speakers serve as intertextual meta-commentaries on the politics of identity, as well as a way for youth to mainstream their previously marginalised voices (Terkourafi 2010; Alim et al. 2009; Morgan 2009; Williams and Stroud 2010), as "[...] self-aware voices [...] that are now beginning to discover their own collective power of analysis both within and across borders" (Sarkar 2009:142) and "[...] poetic voices [...] of a new multilingual, multiracial urban generation seemingly left out of the language planners' calculations [...]" (Sarkar 2009:153). In line with this, Scott (1999:215) asks us to seriously consider the peripheral nature of marginalised voices and how they are implicated in rap performance genres of hip-hop (cf. also Pennycook and Mitchell 2009:40), given that multilingual speakers will always differ across peripheral contexts (cf. Pietikäinen and Kelly-Holmes 2013). Similarly, Alim (2009a:16) urges hip-hop scholars of language to adopt an ethnographic approach in order to document intricacies of multilingualism and identity in localities where global hip-hop is indexicalised for the contextualisation and recontextualisation of local voice. In this paper, we attempt to bring into focus how marginalised voices are mainstreamed in the local cultural practice of hiphop in Cape Town. We do this by approaching rap performances as "[...] encounters in which individuals establish forms of footing and alignment with voices indexed by speech and thus with social types of persons, real or imagined [...]" (Agha 2005:38; cf. also Blommaert 2005). Taking on, and talking through, a diversity of voices is a political act. Thus, the examples we offer of how different rap personae are voiced through the entextualised performance of stylised language (Bauman and Briggs 1990) are offered as instances of everyday politics.

We begin by providing a brief overview of the qualitative changes that multilingualism is undergoing within the context of globalisation. This is followed by a section on braggadocio as a genre of rap and the processes of sampling which are inextricably linked to the performance of this genre. In the analysis of an excerpt of a live braggadocio performance by three emcees ${ }^{1}$, we specifically ask how emcees sample local varieties of language, texts and registers to stage their particular stylisation (Rampton 1999) of voice in the local hip-hop context. We conclude the analysis by suggesting that the emcees' remixing of language varieties and discursive resources in braggadocio carry the voices of a new multilingual, multiracial, urban and rural generation (Shohamy 2006; Heller 2011) and that this ought to have implications for language politics.

\section{Remixing multilingualism and hip-hop in times of globalisation}

Globalising sociolinguistic landscapes are fundamentally changing the way we approach language and what we consider language to be. Arguably, globalisation has reshaped our notions of linguistic communities and multilingual space in that these notions have been shaken up and fault lines laid bare in otherwise taken-for-granted structural-functional mindsets around language (cf. Heller 2007a, 2007b). The idea of bounded and territorially-closed language communities has become obsolete to the extent that spaces have opened up to mobilities and rhythms that are porous and heterogeneous by nature. Globalisation is also ushering in new conditions for the "maintenance and development of various kinds of multilingualism" (Heller 2007b:539), and is refiguring multilingualism in "a new linguistic dispensation" (Aronin and Singleton 2008:1) with "[...] sets of languages, rather than single languages, [that] now perform the essential functions of communication, cognition and identity for individuals and the global

\footnotetext{
${ }^{1}$ The performances were transcribed by the first author and form part of an 18-month-long linguistic ethnographic study on multilingual hip-hop.
} 
community" (Aronin and Singleton 2008:4). As a result, unique configurations of multilingual resources are emerging as young multilingual speakers pursue global and local life trajectories usinsg a combination of very diverse linguistic and semiotic resources. Importantly, globalisation is changing our conception of the complex ways in which multilingual practices mediate local voices in "global" arenas.

One such configuration of multilingual practices, with implications for voice, is the way speakers appear to effortlessly "remix" (Alim 2009a) languages, styles and registers in their multilingual repertoires. Remixing is a process in which the production of new forms of speech, register and styles in local context serves to showcase speakers' identities, cultural authenticities and voice (cf. Lessig 2008; Knobel and Lankshear 2008). According to Lessig (2008:76), to remix is to create a "collage" out of "combining elements" of cultural resources in order to build something new. In Knobel and Lankshears' (2008, in Maher 2010:581) words, "[to] remix means to take cultural artefacts and combine and manipulate them into new kinds of creative blends". In the processes of remixing, semiotic forms previously not read, seen or heard are either deliberately, strategically or serendipitously brought together in unexpected ways and made part of the mainstream politics of identity.

Although linguistic remixing is central to how voice is articulated, it has rarely merited consideration from a language politics point of view. Needless to say, language policy and planning in the South African context have largely been part of the preoccupation with how to contain the undesirable frictions of colonial contact. The role of language in the ordering, compartmentalisation and regulation of populations served to preserve the centrality of desirable identities and to further the marginalisation of those which were less desirable (Kamwangamalu 2004:216). Historically, the South African language policy was tightly linked to the tensions emanating, on the one hand, from an oppressed Dutch-speaking Afrikaner population under British rule, and on the other hand, the threat of the growing black linguistic community very much in the shadow of public life (Giliomee 2003). The protracted language struggle was, at heart, a struggle for ethnic and national identity deeply rooted in Afrikaner consciousness that culminated with the dawn of apartheid (cf. Orman 2008). Thus, the apartheid language policy sui generis willed into law a linguistic ideology. This was in practice "an organic linguistic nationalism" (Orman 2008:86) that required separateness and the fidelity of an Afrikaner demos toward racial distinction; in other words, the survival of the Afrikaner volk (people) in an Afrikaner designed nation-state.

Although post-apartheid South African language policy recognises multilingualism as a resource and heritage, stipulating 11 official languages with parity of esteem, the spirit of linguistic compartmentalisation remains strong. Despite this, recent South African sociolinguistic scholarship has increasingly begun attending to language varieties and dialects left out of official language discourse, namely the marginalised varieties of Kaaps, the register Sabela and Tsotsitaal (cf. e.g. Hurst 2008; Mesthrie 2008; Cuvelier et al. 2010; Dyers 2008; Williams and Stroud 2010). Work on these varieties demonstrates that South African youth find voice within the nooks and crannies outside of, on the periphery, and within the multilingual interstices of institutionalised panopticons of officially recognised languages. Thus, it is not only the case that "[...] remixing presents us with important questions about the supposed oneto-one relationship between language and identity" but also helps us to highlight the "complex, multilayered uses of language $[\ldots]$ that give a more central role to linguistic agency on the part of youth" (Alim 2009b:117). 
The analysis of the data in this study demonstrates how emcees in Cape Town hip-hop perform the remixing of their multilingualism as they sample and stylise languages, registers, personae and voices. Specifically, the data illustrate how the multilingual practices of the emcees navigate global hip-hop authenticity while simultaneously (re)enforcing local hip-hop styles. The analyses reveal how phonological and lexical stylisations of local voice in speakers' everyday practices come to be manifest in the "translocal" braggadocio performance and how multilingual remixing manifests as the linguistic stylisation of historically marginalised language varieties. These are strategically performed by multilingual emcees in the intertextual sampling of rap braggadocio. However, before proceeding to the analysis, a brief description of the history of Cape Town hip-hop and the practice of sampling in rap performances is called for.

\section{Cape Town hip-hop, braggadocio and sampling in performance}

The remixing of global hip-hop in Cape Town started in an era defined by apartheid state violence and censorship, an oppression braved by very few emcees who articulated their suffering and the suffering of others through translocally mixed lyrics (cf. Haupt 1996 and 2008; Nkonyeni 2007; Warner 2007; Watkins 2000). Hip-hop heads ${ }^{2}$ had found in the global hip-hop nation a "connective marginalisation" (Osumare 2007) which served as a common frame of reference for young black and coloured multilingual speakers in township spaces who found solace and comfort in shared circumstances of poverty and discrimination. By 1982, a fledgling hip-hop community had formed and began to apprentice followers into the "style community" (following Alim 2009a) that came to define hip-hop across the greater peninsula of Cape Town (Nkonyeni 2007:156-157). With the emergence of sub-genres of rap such as Spaza- and Zef Rap, Cape Town hip-hop has grown its style community into one that is currently realising its transformative potential by lifting marginalised voices into the spotlight through the mainstreaming of previously marginalised languages.

Since its inception, hip-hop in Cape Town has always had an interesting non-hegemonic relationship with transnational whiteness. From the heady days of the 1980s, coloured hip-hop heads developed this relationship by cultivating a form of hip-hop authenticity that drew heavily on the anti-racism and anti-hegemonic transnational hip-hop nation established in the United States (rearticulating through lyrics the conscious philosophies of Public Enemy, KRS-One, amongst others, and the "each-one-teach-one" philosophy that became part of the anti-racist movement, the Zulu Nation). In one sense (because not all hip-hop heads agree on this point), Cape Town hip-hop became the site where the recontextualisation of a global struggle consciousness was inserted into local struggles against apartheid and the symbolic refiguring of local whiteness (Warner 2007). This took place at the same time as notions of 'colouredness' were undergoing refiguration (Haupt 1997).

Almost twenty years after the first democratic government branded the unifying idea of multiracialism into the metaphor of the rainbow nation (Alexander 2013), new forms of performance genre, such as Spaza Rap (pioneered by black Xhosa hip-hop heads) and Zef Rap (pioneered by white Afrikaans hip-hop heads), are showing that the rainbow nation seems to be, quite disconcertingly, "an optical illusion" (Alexander 2013). In particular, Zef culture has

\footnotetext{
${ }^{2}$ Hip-hop heads are knowledgeable individuals in the hip-hop culture who are not only the core and long-term members (cf. Morgan 2009) but practise, transmit the knowledge and preserve the aesthetic and artistic use of deejaying, emceeing, b-boying, graffiti-writing and knowledge of the self.
} 
become a form of release for white Afrikaner youth amidst an assumed crisis of power, masculinity and sexuality (Kreuger 2012). According to Marx and Milton (2011), Zef culture is reconfiguring Afrikaans whiteness, mediated through "zef" cultural artefacts and performances, in a deliberate attempt to speak "to the perceived sense of marginal and liminal experience of white Afrikaans youth in post-apartheid South Africa" (cf. Marx and Milton 2011:723).

On the other hand, Spaza Rap, a mixture of isiXhosa, Afrikaans and Tsotsitaal, is "a term used to describe rap in isiXhosa. It was invented in Cape Town and is a clear example of the different paths South African hip-hop has taken in diverging from the American model" (Pritchard 2009:54). In an interview published on the blog entitled "The UnderGround Angle", Rattex, one of the leading pioneers of the Spaza Rap genre, reports that when they created it "Spaza was small back in the day - it was all about English raps. English rappers used to call us Kwaito MCs". Becker (2008:10) notes that Spaza rappers "have creatively appropriated hip-hop in their quest for alternative, fluid, consciously 'African' identities in contemporary South Africa" and that music, clothing and embodiment among young isiXhosa-speaking hip-hop artists in a Cape Town township "did not necessarily entail the confirmation of old, or the construction of new [ethnicised/racialised] boundaries" (Becker 2008:11; Becker and Dastille 2008).

\subsection{Braggadocio, sampling and remixing}

In both Zef- and Spaza Rap, as well as the more "conscious, everyday rap" of Cape Town hiphop, examples of linguistic remixing can be found in the performance of the rap genre braggadocio (bragging or bravado). In global hip-hop, celebrating rap styles and boasting about success is a ubiquitous practice (Rose 2008). An emcee performing on stage would often rap about topics such as his/her sexual exploits, physical attractiveness, accumulation of money, how much "swagger" (coolness) s/he has and how linguistically skilled s/he is. According to Smitherman (1997:12-13), "braggadocio is richly interwoven into the everyday AAL ${ }^{4}$ conversational context, and it is ritualized in the toasts, longstanding epics from the oral tradition". It requires creative and artistic skill, clever multivocal languaging (Higgins 2009:112) and the proverbial gift of the gab to brag about exploits, promote particular rap styles and represent place and rap groups (or "crews"). It is, as Higgins (2009:113) defines it, a form of "self-praise" which "echo[es] both local and global cultural practices at the same time". In the performance of lyrical content and rhyming, emcees continuously use braggadocio to performatively index aspects of "keeping it real" (to always be true to yourself and your rap group at any cost) and "representin"" (to always remain true to where you come from). Emcees may use it to disrespect (or "diss") their fellow hip-hop peers or relegate them to the margins by negating their "[...] attributes [physical or otherwise] while praising one's own" (Keyes 2002:137). This sometimes leads to conflict with other emcees, especially among different rap groups.

To perform braggadocio, especially in the South African hip-hop context, multilingual emcees draw on or sample varieties of language, registers, speech styles and social aspects of life in the township - the sociolinguistic ingredients for staging voice in multilingual modes. The notion of 'sampling' stems from the idea of sounds and styles being meshed together by selectively

\footnotetext{
${ }^{3} \mathrm{Cf}$. the following link: http://theundergroundangle.blogspot.no/2009/04/if-youve-ever-heard-driemanskapjoint.html (accessed 2 September 2013).

4 African-American Language.
} 
adopting various existing sounds, beats, styles and personae in order to produce mimesis and hybridity. Rap music has always been about sampling texts, language and registers (Potter 1995:53), and emcees have customarily defined their particular artistic profiles in terms of their individual polylingual and polysemic practices.

The manner in which sampling practices have developed since the inception of hip-hop and rap music in the 1970s has changed significantly, with the speed of change fuelled by present-day globalisation (Rose 1994:89). The way emcees display their voices and personae via braggadocio rests fundamentally on employing creative practices of intertextuality. As such, sampling can be seen as a specific type of intertextuality in the hip-hop context.

Bauman (2004:4) defines "intertextuality" as the "relational orientation of a text to other texts" (cf. also Androutsopoulos 2009:45). Intertextuality resembles the iterability of texts in linguistic practices and performances such as parody and plays. The notion is captured most powerfully by Bakhtin (1986:162) who argues that texts are constantly negotiated in their use together as part of contexts. It is there where they "speak" to each other in dialogic ways and come into contact as texts, because behind every text is a complexity of "personalities". In our analysis in the following sections, we find intertextuality at the interplay or nexus of dialogue that exists between texts.

Thus, the question we pose here pertains to how marginalised voice is stylised in lyrical and multilingual recontextualisations of texts and genres. In other words, we analyse the linguistic means for sampling and stylisation of language employed by emcees that will speak to the question of how marginalised voices are promoted through multilingualism. In the following section, we explore the ways in which the genre of braggadocio samples intertextual and translocal forms, remixes these in local multilingual practices and then makes visible voices on the margins. We also show how these performances connect global hip-hop to the uses of language and voice found in the "everydayness" of multilingualism in Cape Town.

\section{A MobCoW $W^{5}$ performance: Remixing, sampling and stylising voices}

In this section, we will analyse a performance of linguistic remixing by members of the extended rap group MobCoW. We draw here on the linguistic ethnographic fieldwork which was completed by the first author as part of his doctoral dissertation which focused on the multilingual rap performances during a hip-hop show in a popular nightclub in Kuilsriver in the Northern Suburbs of Cape Town. The first author observed and made video recordings of rap performances by emcees of the rap group known as "Suburban Menace". As an all-male rap group, Suburban Menace was the first out of the MobCoW family to perform in front of an audience, to whom they presented a packaged and polished rehearsal every night in their regular showdown in Club Stones. In this venue, fans and hip-hop heads have long been treated to new ways of using local languages to express emerging rap styles and identities in the form of Suburban Menace's mixtape $\mathrm{CDs}^{6}$. In the hip-hop community at this time (2008), it was

\footnotetext{
${ }^{5}$ The name "MobCoW" is derived from the stage name and real name of the two leading members of the group, namely MoB (stage name) and Mr Cow (pseudonym), the latter of whom is the producer of Suburban Menace's rap music.

${ }^{6}$ In the run-up to their debut album, members of Suburban Menace wrote lyrics for a mixtape CD to give their fans an idea of the quality and rich texture of their message. A Suburban Menace mixtape CD would comprise a
} 
rumoured that the MobCoW family had become firmly established and was well-known for monthly releases of mixtape CDs; emcees of the family were guaranteed that fans and hip-hop peers were listening to their rap poetry. For a while, the family members would only record in the studio. However, the emcees later decided that they would perform together on-stage in front of a live local audience. They had to "represent" the family, that is, be authentically MobCoW in every performance. ${ }^{7}$

On 19 March 2009, Lil Holmes and CC (hip-hop heads and members of MobCoW) hosted the hip-hop show in Club Stones. In this event, local emcees de-emphasised the use of English which, up until now, had largely defined the braggadocio genre by linking non-dominant varieties of language and registers in their performance to produce a "secondary genre" (Bakhtin 1986:62) - a local intertextual braggadocio. This was deliberately set up to stylise local voice as they "absorb and digest various primary (simple) genres" (Bakhtin 1986:62). In their performance, MobCoW linked particular forms of speech and their functions (Mesthrie 2008) to the generic model of braggadocio and, in the process, recontextualised the genre to fit the local context.

The evening started with a set programme which included booked rappers and emcees who were to perform, various promotions and drinking games. At about 21h00, Lil Holmes stepped on stage and opened the show. DJ Earl Scratch faded the music and Lil Holmes presented the first act for the evening under the theme "No Stones Unturned". He quipped, "Once again Wednesday nights, Suburban Menace in the house. I got my boys Boesmankamp [Bushman Camp] in the house tonight, some tight emcees. I want to give some thanks to Wendell, the main hustler. Hy sponse' vanaand se event vi' ons [He is sponsoring tonight's event for us]. His laces is 20 bucks, hey, and a mixtape is 30 bucks." The audience listened attentively.

After Boesmankamp's performance, Lil Holmes readied the audience for the performances by the MobCoW family by asking whether they were ready for Suburban Menace and other emcees, to which the audience responded with loud cheers. He then turned to DJ Earl Scratch and motioned to him to play the rap music (beats). At that point, MoB and M.D.K. stepped on stage with their microphones in hand, nodding their heads to the music, and began the performance. M.D.K.'s performance was largely inaudible because of technical difficulties but MoB hurriedly continued the performance for the sake of on-stage continuity. This was followed by a performance from MC Cole, a Kaaps emcee, whose lyrics consisted mainly of the self-aggrandisement of his style. After MC Cole's performance, MoB initiated the following call-and-response ${ }^{8}$ with the audience, giving time for the next performer, Narc, to take centre stage:

recognisable rap instrumental (or beat) overlaid by the respective Suburban Menace emcees' lyrics, and mixed by a well-known deejay.

${ }^{7}$ The emcees in the Suburban Menace group are multilingual lyricists who grew up in Kuilsriver. All of the members were influenced by hip-hop from the USA. Their search for local ways to develop the hip-hop culture in Cape Town makes their linguistic remixing practices an interesting topic for analysis.

${ }^{8}$ According to Smitherman (1977:104), call-and-response is the "spontaneous verbal and non-verbal interaction between speaker and listener in which all of the statements ('calls') are punctuated by expressions ('responses') from the listener". 


\section{Call-and-Response Excerpt 1:}

MoB:

$85 \quad$ Make some noise!

86 Audience: whoo!!

87 OK

88 Can we bring Chuck back on to the stage?

[Motions to Chuck and Baza Lo but Narc comes instead]

89 Make some noise for N-A-R-C (spells Narc, short for Narcotics)!

Narc:

$90 \quad$ Yeah!

91 Put your hands up

92 I say put your hands up

93 Yeah!

94 Uh

MoB:

95 Come on

96 Come on

97 Yeah

\section{Performance}

Narc:

$98 \quad$ Yeah

99 Yeah

100 I got a superrag man

101 Call me supaswag man

102 And I spit this shit

103 Like I just won a grandslam

104 Yeah

105 I'm a Caped Crusader

106 And I don't [inaudible]

107 I don't hate you haters

108 [inaudible] for me

109 To make my paper

110 [inaudible]

111 Music is my saviour

112 I'm what music gave

113 Yeah

114 Alright

115 OK

116 I don't hate 

117 No way
118 I just let these motherfuckas
119 Get a thirst of my swag
120 I smoke them quicker than a drag
121 Cause you struggle with the basics
122 I keep it real
123 You guys are living in a matrix

The sampling of call-and-response is a common generic feature of both global and local hiphop (cf. Ariefdien and Burgess 2011). It is strategically figured by emcees as a structural feature that prepares for transitions between different forms of braggadocio. The call-and-response in lines 85-90, initiated by the leading emcee, $\mathrm{MoB}$, has a double function in that he holds the attention of the audience whilst introducing rap figures and personae on to the stage. As MoB introduces the next few emcees to the audience, he realises that Narc has already stepped on stage and so, instead of stopping Narc's performance, they both engage in verbal cueing for the sake of stage continuity (e.g. "Yeah" in lines 90 and 97-99 respectively).

Verbal cueing is an important performative strategy employed by emcees in rap performances. The purpose of verbal cueing in the performance in Excerpt 1 is to structure the lyrics that Narc is searching to perform. He eventually succeeds in doing so from line 100 onwards. Unlike the emcees that performed before him, Narc performs his braggadocio in a way that showed the "cool" side of his identity (or his "swagger"). According to Kearns (2010:1), swagger is the

[...] mindset of fearing nothing, complete self-determination above and beyond any laws, moral codes or social norms, and the intention to back all of this up without hesitation, by any means necessary, be it wealth, weapons or women.

From line 100 onwards, Narc promotes his rap authenticity in a localised form of swag, making local references to Cape Crusader (line 105) to signify his message. Although an underresearched performance genre, swag is often misunderstood outside the cultural world of hiphop as inspiring conventional differences and as enforcing seemingly simplistic stylisations among hip-hop heads themselves. However, it is argued here that swag is a form of sampling that becomes decontextualised, is iterable and contributes to the overall coherence of braggadocio in local hip-hop contexts. In Narc's performance, for example, a variety of different intertextual relations are brought together in the sampling of swagger lyrics. Firstly, his performance is in a variety of English which is stylised in accented African-American English (AAE), therefore providing linguistic evidence for the display of global hip-hop authenticity.

Secondly, the sampling of swagger lyrics into the broader structure of this instance of braggadocio makes for interesting reflection because the overuse of the verbal cue "Yeah" (seven in total) is usually not a significant feature of the braggadocio performance. This may indicate that Narc struggled to remember his "writtens", or written and rehearsed lyrics (cf. Lee $2009 a ; 2009 b)$. He stylises not only the verbal cue in accented-AAE but also AfricanAmericanised lexical items such as "supaswag" (line 101) and "muthafuckas" (line 118).

One single intertextual theme runs through Narc's lyrical content, namely the present or future jealousy from his fellow hip-hop heads, labelled here as the "haters". The term "hater" is linked 
to the celebration of commercial success among emcees in hip-hop communities across the world. According to Perry (2004:48), who comments on hip-hop in the USA, hating is " [...] thrown at those imagined to be envious of one's wealth or abundant suitors" (cf. also Boyd 2004:114). For instance, Narc's performance suggests that in order to refrain from direct confrontation with him and his crew, to "keep it real", they need haters because without them the crew cannot "make [the] paper" (line 109). To this end, Narc's sampling of swagger lyrics, in a broader sense, recontextualises the performance of braggadocio through the global language variety AAE.

Like rap in the USA, Narc's performance in accented-AAE would not necessarily be brought into question. However, in the local context of the hip-hop show, his performance is an attempt to performatively link up with the other emcees performing braggadocio through language varieties or accented-Englishes. We see that Narc's entire lyrical structure is outlined by toasting his swagger intertextually. Although swagger is often understudied by hip-hop linguists, its history as a text set in global linguistic flows (cf. Alim et al. 2009) is important because emcees associate swagger with a kind of "coolness" or with the pimping culture of American rap in the southern states of the USA (Perry 2004).

Thus we see that Narc's attempts to incorporate swagger lyrics and stylise accented-AAE in the braggadocio taps into the processes of mainstreaming marginalised voices. The literature on the politics of English in the USA surrounding AAE has opened up a space for dialogue around the linguistic voice of previously marginalised citizens in that country. Researchers like Smitherman $(1977,2000)$ and Alim (2004) have shown that it is not enough to recognise the creative capacity of speakers in order to mainstream voice; we also need to recognise what these voices signify. It is no coincidence that similar debates surrounding the linguistic imperialism of English and the mainstreaming of historically marginalised varieties (such as Black South African English and Coloured South African English, to name a few) are still raging amongst academics and policy makers (cf. Mesthrie 2010). Nevertheless, what we see Narc achieve here is a display of an awareness and recognition of language varieties in his surroundings and the semiotics of performing in a global language variety which, in the process, gives others a sense of what they can do phonologically or lexically in order to remix their multilingualism. What is remixed here is not only AAE but also a version of South African English to stylise Narc's local voice. As a consequence of finding himself in a local space, then, Narc chose to demonstrate to the audience that he is able to draw on different linguistic voices, which are tied to his rap identity and authenticity, in order to link up to other types of voices (e.g. country and black African-American voices).

After Narc's performance ended, MoB returned to sample again a call-and-response to continue his rendition of braggadocio in the local space. The last two emcees to end the performance were Chuck and Baza Lo. As they stepped onto the stage, they were met by a highly expectant audience as this was the first time they had performed together. There was great anticipation in the air and many of the MobCoW family members hoped the combination of Baza Lo (an isiXhosa/Sesotho multilingual emcee) and Chuck (an emcee with language knowledge of Kaaps/Sabela) would not only contribute to the racial diversity of the group, but also complement the multilingualism of the group and the development of the style community. As with the previous one, the following call-and-response structured the way toward the main performance: 


\section{Call-and-Response Excerpt 2:}

Narc:

$\begin{array}{ll}124 & \text { OK } \\ 125 & \text { No way } \\ 126 & \text { I get okay } \\ 127 & \text { I need cash OK }\end{array}$

MoB:

128 Alright

Narc:

129 OK

Performance:

\section{Chuck:}

\begin{tabular}{|c|c|}
\hline 130 & Alright \\
\hline 131 & $\mathrm{OK}$ \\
\hline 132 & I don't dance \\
\hline 133 & No way \\
\hline 134 & I just [inaudible] \\
\hline & My style is fokkol \\
\hline & My style is nothing \\
\hline & My broe' \\
\hline & My brother \\
\hline & Djy sal wat mens kan tokkel \\
\hline & You'll have to speak up \\
\hline & Djy sal moet koppel \\
\hline & You need to connect \\
\hline & Sterk Emcees moet kophou \\
\hline & Tough Emcees keep up \\
\hline & I'm strong for ghettos \\
\hline & I'm strong for the ghettos \\
\hline & Soe verlap in die ghettos \\
\hline & So downtrodden in the ghettos \\
\hline & Emcees maak verplette \\
\hline & Emcees I murder \\
\hline & Maar belieg kapettos \\
\hline & I lied I axe you \\
\hline & "Ek moet my bek hou" \\
\hline & "I need to shut up" \\
\hline & Terror sê soe \\
\hline & Terror said so \\
\hline
\end{tabular}


146 Ek sê, "Nie, I let go"

I say, "No, I let go"

147 Want ek het jou

Cause I got you

148 Djy lat my waarheid

I'll be true

149 Maar uithou

Gotta keep at it

150 Verstaan jou ma

Understand your mother

151 Djy dra haa' bra van kan dikhou

You wear her brassiere cause you persistent

152 Ko' haal jou piel

Come get dicked

153 Die string het jou flow

My cadence got your flow

154 [inaudible] my beat kannie uithou

[inaudible] my beat lasts longer

155 Volwassenes

Grown ups

156 Masters

Masters

157 Wat djy ko' dophou

You need to come and watch

158 Anders sal djy nooit kan getuig van the Chuck $(\mathrm{Ou})$

Otherwise you'll never bear witness of Chuck (Ou)

159 Die only true Emcee

The only true Emcee

160 Wat die laities nou gan vashou

Keeping kids' attention

161 [inaudible]

162 In die Filistyn

In Philistine

163 Emcees op julle getrain

Emcees, I trained on you

164 My style is freestyle

My style is freestyle

165 And my stuil will remain

And my style will remain

Similar to that of Narc, the performance by Chuck presented here can be viewed as a combination of sampled texts as well as an attempt to absorb these texts into the generic structure of the braggadocio genre. Like the other emcees that went before him, the audience expects Chuck to draw on texts that have already been sampled (bragging, metaphors, idiomatic expressions, etc.). However, Chuck surprises by performing a very different form of sampling which impacts significantly on the intertextuality of the local braggadocio performance. 
At the beginning of his performance, although it is not immediately clear, Chuck addresses either someone in the audience or somebody out of sight. He starts performing simultaneously with the end of the call-and-response, suggesting to the audience that he is not an emcee that dances to the beat of others (line 132). This proclamation of "not dancing" is a sufficient segue into the entextualisation of an incident which occurred in global hip-hop. At the 1995 Source Awards in New York, amidst the East vs. West Coast rap battle, Death Row Records CEO Suge Knight (representing the West Coast) "dissed" Sean "Puffy" Combs, the founder of New Yorkbased Bad Boy Records, for not only dancing in his music videos but also in music videos by artists signed to his record label. Knight had proposed that New York City-based artists deflect from Combs' label, saying, amongst other things:

Any of you artists out there that want to be an artist and wanna stay a star, and don't have to worry about the executive producer trying to be all in the videos, all on the records, dancing, come to Death Row! ${ }^{9}$

Knight's statement was viewed as contentious and fanned the proverbial flames of the on-going East vs. West Coast rap battle. To relate this back to the present context, Chuck performs lyrics of not dancing to preempt a tough stance (Jaffe 2009) in the context of the hip-hop show in Club Stones. For instance, from lines 136 to 138, it is still unclear who he is addressing, but what is clear is that he uses a number of Sabela phrases to suggest that whoever addresses him lyrically will have to speak up (line 137) if s/he wants to connect to his braggadocio (line 138). Only after these lyrical lines have been uttered do we understand that his intended audience is all the tough emcees in the crowd who also need to keep up (line 139).

By opening his performance in Kaaps and the register Sabela, Chuck's use of words such as "koppel" sets the stage for a lyrical battle with an emcee in the audience, as he warns: "Sterk Emcees moet kophou" (Tough Emcees need to keep up, line 139). The sampling of these lyrics is set in the general structure of the local braggadocio as Chuck raps that he is not a stereotypical emcee when it concerns representing his place because he is "strong for ghettos" (line 140). He is also mindful of what is "verlap in die ghettos" (downtrodden in the ghettos, line 141). He refers to his socio-economic condition and attempts to relate to audience members who are also downtrodden in the ghettos. In this way, Chuck celebrates a particular style of rap by referencing "ghetto" and by emphasising the inequalities in townships. According to Gerard and Sidnell (2003:282), emcees "[...] offer spatial descriptions that include place-names [which] are often received with expressions of appreciation (for example, applause), and as such these descriptions provide opportunities for audience members to engage as active participants". Here we can clearly see how the emcee uses "keeping it real" and linguistic virtuosity as metrics for evaluating what types of sampling (do not) fit in the relocalising of the braggadocio, as the sampling of a different text is introduced in his performance.

In subsequent lyrics performed in Kaaps and Sabela (from lines 144 to 154) Chuck samples in the genre of "beef". According to Smitherman (2000:65), beef can be understood as "conflict, squabble, a problem" between rap groups or crews over one or several particular issues. Similarly, Fitzpatrick (2005:6) states that "[ ...] beef is a long-standing disagreement between individuals or groups. The different sides in a beef may use battling as a way to defame the other side, although this is not necessary". In our example, Chuck gives the impression that

\footnotetext{
${ }^{9}$ This quote was transcribed from the following link: http://www.youtube.com/watch?v=JpgpS3ogvMM (accessed 20 November 2013).
} 
someone else started beef with him by saying he should shut up (line 144). To elaborate, we see him perform the quoted lyric "Ek moet my bek hou" (I need to shut up) which is sampled from an earlier performance by Terror MC, a veteran emcee in the local hip-hop community of Cape Town. This sampling is an indication that Chuck is infuriated because if there was any beef between him and Terror, they could have settled it on stage in a freestyle rap battle - one of the more standard and agreed-upon ways of settling beef. Secondly, as a result, this has Chuck replying with battle lyrics in a braggadocio performative frame, using attacking rhymes with gusto (line 146) but refraining from any physical encounters (lines 148 to 149). Interestingly, by performing in Kaaps and Sabela, Chuck mediates his beef by sampling discourse aspects of tough masculinity in his lyrics. He subjects Terror MC to a vicious, emasculating attack by suggesting that he wears a brassiere (line 151) and walks around with a castrated phallus (line 152). As a result, Chuck moves out of battle genre mode to perform braggadocio lyrics and suggests to Terror MC and the audience that he is the only true emcee (line 159) and that his style (of braggadocio) will remain (line 165).

Chuck is the only member of the MobCoW family who has had significant exposure to Sabela. His rap style incorporates the physical mannerisms and gesturing that are often associated with the Number gangs in Cape Town ${ }^{10}$. His entextualisation of rap braggadocio is unique in comparison to the more global-like performances by $\mathrm{MoB}$ and Narc as it is relocalised to the extreme local (cf. Williams and Stroud 2010) by being performed in Sabela, a register which shares a lot of vocabulary with Kaaps. This sets Chuck apart from the rest of the MobCoW family, as does the way in which his braggadocio lyrics overlap with his performance of beef which, on the surface, seems disorganised. However, Chuck seems to view this as an encouraging way of performing his braggadocio, linking Sabela and Kaaps to the local generic model of the genre.

What is clearly achieved by Chuck's performance is the in-mixing of Sabela and Kaaps into the larger hip-hop space of the show. Specifically related to his performance, he remixes multilingualism on stage by according strategic importance to Sabela, which is used here to perform beef lyrics. At the same time, Chuck also highlights the performative relevance of Kaaps. Given the history of marginalisation surrounding the use of Kaaps (cf. Prah 2012), he stylises (unintentionally and perhaps without a larger purpose) this Afrikaans variety for the purpose of mainstreaming his own linguistic voice and that of other audience members who share in that voice.

The final performance of braggadocio was that of emcee Baza Lo. For the first time, we find no call-and-response but rather an abrupt move with no overlap by Baza Lo, the emcee performing straight after Chuck:

\section{Baza Lo:}

166 Baza, Baza lo, phum' enkonzweni This is Baza, Baza, straight out of church

167 Gcwala ngifun' ozong'tshela

Recognise what I want, who's going to tell me

168 I wanna hear ozong'tshela

${ }^{10}$ The Number gangs are a well-known feature of South African prison life. There are three groupings, namely the 26s, 27s and 28s (cf. Steinberg 2004). 
I want to hear who's going to tell me

169 Yes, xa ungamkele ngwana woza uzong'thola

Yes, if you've accepted me girl come get me

170 Lana ngipeth' uBaza, Baza, bheka ngubani ozo ndicrossa?

Hear, I have Baza, Baza, who is going cross me?

171 Ngithi ng'rap apha

I say I rap here

172 [inaudible]

173 Lapha mfana abang'funi

They don't want me here dude

174 Ukuthi vel uzong'thola

Because they know they'll get me

175 Hahaha

176 Kuhleli zona zodwa

Only they are sitting here

177 Apha ng'hleli nabantwana vele uzogcwala, yes!

Here I'm sitting with girls, of course you'll appreciate, yes!

178 S'pheth' ighetto mfethu

We own the ghetto my friend

179 Abantwana bathi "Sifun' ukuth' uvele uzoyithola"

Girls say "We want you to come and get it"

180 Izokuphel' imali yotwala, vele ng'lapha ebackdoor

Money for alcohol is going to end, I'm at the backdoor

181 Ek willie praat van jou

I don't want to talk about you

182 S'phth' i-cheque nou

We have the cheques right now

183 Staan op, my penis, vele san' uzoythola

Stand up on my penis, of course, you'll get it

184 Abantwana ba-"skriekie" - ek, believe uzothola

Girls are "skriekie" - I believe you'll get it

185 En hy's skaam van jou

And he's shy for you

186 Abantwana sbathol'

We'll get the girls

187 [inaudible]

188 Ghetto Style baba!

189 Ghetto Style baba!

Here, Baza Lo is performing in isiXhosa, English and Kaaps. He is the only emcee on stage who is able to perform lyrics employing these three linguistic resources. As his performance unfolds from line 166, it is difficult to discern whether he samples one or another intertextual relation absorbed in the braggadocio by his crew members. It is also unclear whether he samples swagger or beef texts. One could argue that he is performing a non-intertextualisable braggadocio which perhaps would be the whole point of his performance. However, on the surface of his braggadocio's supposed incoherence, Baza Lo's lyrics entextualise an eKasi style of rap (an emerging rap genre created in black townships across South Africa) that is strongly linked to the practice of Spaza Rap. He boasts about his masculinity and his "supaswag" is self- 
evident as he boasts not only to women but also to the "haters" (line 173) that he has cheques (line 182) and all the women. Spaza Rap uses isiXhosa, a variety of South African English, Kaaps and other language forms from various Bantu languages to comment on the realities of black township life. In addition, Spaza Rap celebrates and criticises the politics of the new black middle class. Baza Lo, however, does not seem to do the latter but rather the former. In doing so, he introduces into the braggadocio performance a stylisation of isiXhosa, English and Kaaps as a way to resemiotise (Jacquemet 2005) the "gangsta-pimp-ho" discourse prevalent in global hip-hop (Rose 2008; Sharpley-Whiting 2007). In turn, he samples an eKasi streetsmart persona for the benefit of the audience.

The task Baza Lo challenges us with is to read his persona as an intertextual and interpersonal event. According to Agha (2007:239), "like any semiotic activity, the activity of reading persons has a text-in-context organisation in any given interpersonal encounter; it is shaped by text-level indexical effects. But it is also mediated by stereotypes of indexicality, namely stereotypical social images associated with discrete signs that specify default ways of reading persons who display them". The linguistic strategies Baza Lo employs in his lyrics are mediations about his persona, "Baza, Baza" (line 166), a tough eKasi guy who is streetsmart about women and rap. Similar to Chuck's performance, we find that Baza Lo metapragmatically suggests that "Baza, Baza" is the guy that nobody should attempt to assail (line 170). Secondly, the emcee suggests that he does not necessarily feel out of place in the context of Club Stones and cares very little for being accepted because he owns the ghetto and the women as well as having money in plenty. Although he performs that he raps here, it is difficult for him to do so because nobody wants him in the place (lines 171-173).

In his live performance, Baza Lo reflects on some of his audience members not being able to understand him, not because he performs in isiXhosa but because some may be jealous of him because he has all the women. Who "they" are, as referred to in line 174, is an intriguing reinforcement of the challenge to haters. The emcee shrugs off his haters and suggests that he is made to feel accepted because of all the women seated near and around him (line 177). The celebration of money and success is a global aspect of hip-hop, but in the case of Baza Lo's braggadocio performance, we clearly see a number of intertextual relations of a locally-scaled nature sampled into the generic model of that genre.

The remaining lyrics in Baza Lo's performance (lines 180-189) are a reinforcement of stereotypical images of women and how he finds them alluring. In addition, these lyrics reinforce the eKasi rap persona. He toasts this style of rap as an enregistered "Ghetto Style" in the performance. The reference to the ghetto reinforces the "gangsta-pimp-ho" image and simultaneously recontextualises the braggadocio performance space as one where ghetto style is allowed. Thus Baza Lo's performance mediates a semiotics of feeling out-of-place, but we nevertheless see him remix his multilingualism in an attempt to open up conditions for an eKasi persona to be accommodated by the braggadocio.

\section{Concluding remarks}

In this article, we organised our argument around the issue of how locally marginalised voices were stylised in the performance of the rap genre known as "braggadocio". We pointed out that the emcees constantly draw on the local cultural terrains of Cape Town and its outlaying townships to highlight the nature of marginalised linguistic voice. In particular, we suggested 
that these voices are translocal and are shaped by recent intensities of deepening diversities as well as the performance of new forms of entangled selves in South Africa (Nuttall 2009). The data demonstrate that voice, as performed through braggadocio, centres on intertextual relations and rap personae. These personae are exaggerated by the performativity of rap texts absorbed in the general model of braggadocio and creatively assembled in the staged event.

We introduced the notions of 'sampling' and 'stylisation of multilingualism' as ways in which to account for the creative and performative processes emcees undertake to put their marginalised voices on display. Interestingly, in their multivocal performances of braggadocio, each emcee lays emphasis on different ways of doing so - by sampling everyday texts, stylising local forms of language varieties and by remixing into this other varieties of language (such as the use of accented-AAE) and registers such as Sabela. This allows them to relocalise the genre at the same time as they are able to promote their authenticity by "keeping it real", displaying unique linguistic virtuosity and scoring on all relevant metrics for evaluating the genre.

Given what the analysis has revealed about how local voices are multilingually remixed and "globalised", a case can be made for a more serious study of the political and social implications of the practices and performances of multilingual speakers in non-institutionalised spaces, such as that of hip-hop. At this point, three questions immediately arise:

(i) Why should this sort of practice be subject to language-political deliberation at all?;

(ii) In what way are the emcee's or emcees' performances political?; and

(iii) In what way can their performances be the seeds of social change?

To answer these questions, we suggest that language politics ought to be about more than just providing resources for education and employment markets, or about the institutionalisation of official bilingualism. In a country such as South Africa, with its history of divisions along racial and linguistic lines, an important task for a politics of language is to recognise the semiotic practices that allow people to "reach out", transgress boundaries, stylise and appropriate indexicalities of the Other whilst ignoring the violence of linguistic regulation that inevitably perpetuates such divisions. Roth-Gordon (2009:64) has pointed to the "seamless integration of rap lyrics into everyday speech". In her study on conversational sampling among Brazilian youth, she notes how young multilingual Brazilians drew on familiar phrases of hip-hop in their conversations, producing an accurate use of famous lyrics for the purpose of conversational alignment. In braggadocio, emcees sample texts, language forms and their functions to highlight local multilingual practices (Rampton 2006; Androutsopoulos 2006; Forman and Neal 2004:209). There is thus a circulation of semiotic forms across everyday spaces of multilingual youth. Our point is simply that studying practices such as hip-hop informs us about how fluidity is accomplished as a convivial feature of everyday life, and how ostensibly stable categories of identity may be eroded through marginal linguistic practices - how being heard and having voice is very much about stylisation and crossing and perhaps less about what is said. However, the challenge remains as to how to incorporate the voices of a new multilingual, multiracial, urban and rural generation (cf. Shohamy 2006; Heller 2011) into a framework for a multilingual policy. This challenge has been around for some time but, as we argue in closing, it is a necessary challenge to tackle if we are to counter the recurrent assumption that multilingualism is a monoglot phenomenon. 


\section{Acknowledgements}

We would like to thank the Flemish Interuniversity Council (VLIR-DBBS, UWC) and the Deputy-Vice Chancellor of Research at the University of the Western Cape for funding the research towards this paper. Our thanks also go to the Max Planck Institute for the Study of Religious and Ethnic Diversity in the authoring of this work.

\section{References}

Agha, A. 2005. Voice, footing, enregisterment. Journal of Linguistic Anthropology 15(1): 3859.

Agha, A. 2007. Language and social relations. Cambridge: Cambridge University Press.

Alexander, N. 2013. Thoughts on the new South Africa. Johannesburg: Jacana.

Alim, H.S. 2004. You know my steez: An ethnographic and sociolinguistic study of styleshifting in a Black African speech community. Durham, NC: Duke University Press.

Alim, H.S. 2009a. Translocal style communities: Hip-hop youth as cultural theorists of style, language, and globalization. Pragmatics 19(1): 103-127.

Alim, H.S. 2009b. Introduction. In H.S. Alim, A. Ibrahim and A. Pennycook (eds.) Global linguistic flows: Hip-hop cultures, youth identities, and the politics of language. London: Routledge. pp. 1-24.

Alim, H.S., A. Ibrahim and A. Pennycook (eds.) 2009. Global linguistic flows: Hip-hop cultures, youth identities, and the politics of language. London: Routledge.

Androutsopoulos, J. 2006. Recontextualization: Hip-hop culture and rap lyrics in Europe. In A. Linke and J. Tanner (eds.) Attraktion und Abwehr. Die Amerikanisierung der Alltagskultur in Europa. Köln: Böhlau. pp. 289-305.

Androutsopoulos, J. 2009. Language and the three spheres of hip-hop. In H.S. Alim, A. Ibrahim and A. Pennycook (eds.) Global linguistic flows: Hip-hop cultures, youth identities, and the politics of language. London: Routledge. pp. 43-62.

Ariefdien, S. and M. Burgess. 2011. Putting two heads together: A cross-generational conversation about hip-hop in a changing South Africa. In P.K. Saucier (ed.) 2011. Native tongue: An African hip-hop reader. New Jersey: Africa World Press. pp. 219-252.

Aronin, L. and D. Singleton. 2008. Multilingualism as a new linguistic dispensation. International Journal of Multilingualism 5(1): 1-16.

Bakhtin, M.M. 1986. Speech genres and other late essays. Austin, TX: University of Texas Press. 
Bauman, R. 2004. A world of others' words: Cross-cultural perspectives on intertextuality. Oxford: Blackwell.

Bauman, R. and C. Briggs. 1990. Poetics of performance as critical perspectives on language and social life. Annual Review of Anthropology 19: 59-88.

Becker, H. 2008. Negotiating culture in contemporary South Africa: Photographic selfrepresentations from the Cape Flats. CODESRIA. pp. 1-43.

Becker, H. and N. Dastile. 2008. Global and African: Exploring hip-hop artists in Philippi township, Cape Town. Anthropology Southern Africa 31 (1\&2): 20-30.

Besnier, N. 2009. Gossip and the everyday production of politics. Honolulu: University of Hawai'i Press.

Blommaert, J. 2005. Discourse: A critical introduction. Cambridge: Cambridge University Press.

Boyd, T. 2004. The new HNIC: The death of the civil rights and the rise of hip-hop. New York: New York University Press.

Cuvelier, P., T. Du Plessis, M. Meeuwis, R. Vandekerckhove and V. Webb (eds.) 2010. Multilingualism from below. Pretoria: Van Schaik Publishers.

Dyers, C. 2008. Truncated multilingualism or language shift? An examination of language use in intimate domains in a new non-racial working-class township in South Africa. Journal of Multilingual and Multicultural Development (29): 110-126.

Fitzpatrick, J.M. 2005. What's beef: Discourse practices of battling in hip-hop language. Unpublished MA thesis. Raleigh: North Carolina State University.

Forman, M. and M.A. Neal (eds.) 2004. That's the joint! The hip-hop studies reader. New York: Routledge.

Gerard, M. and J. Sidnell. 2003. Trying to break it down: MCs' talk and social setting in drum and bass performance. In H.M. Berger and M.T. Carroll (eds.) Global pop, local language. Jackson: University of Mississippi Press. pp. 269-290.

Giliomee, H. 2003. The Afrikaners: Biography of a people. Paarl: Tafelberg.

Haupt, A. 1996. Rap and the articulation of resistance: An exploration of subversive cultural production during the early 90s, with particular reference to Prophets of da City. Unpublished MA mini-thesis. University of the Western Cape.

Haupt, A. 2008. Stealing empire: P2P, intellectual property and hip-hop subversion. Cape Town: HSRC Press.

Heller, M. (ed.) 2007a. Bilingualism: A social approach. New York: Palgrave McMillan. 
Heller, M. 2007b. Multilingualism and transnationalism. In P. Auer and L. Wei (eds.) Handbook of multilingualism and multilingual communication. New York: Mouton de Gruyter. pp. 539-554.

Heller, M. 2011. Paths to post-nationalism: A critical ethnography of language and identity. Oxford: Oxford University Press.

Higgins, C. 2009. From 'da bomb' to bomba: Global hip hop nation language in Tanzania. In H.S. Alim, A. Ibrahim and A. Pennycook (eds.) Global linguistic flows: Hip-hop cultures, youth identities, and the politics of language. London: Routledge. pp. 95-112.

Hurst, E. 2008. Style, structure and function in Cape Town Tsotsitaal. Unpublished PhD dissertation. Cape Town: University of the Western Cape.

Jacquemet, M. 2005. Transidiomatic practices: Language and power in the age of globalization. Journal of Language and Communication 25: 257-277.

Jaffe, A. (ed.) 2009. Stance: Sociolinguistic perspectives. Oxford: Oxford University Press.

Kamwangamalu, N.M. 2004. The language planning situation in South Africa. In R.B. Baldauf and R.B. Kaplan (eds.) Language policy and planning in Africa. Vol.1: Botswana, Malawi, Mozambique and South Africa. Clevedon: Multilingual Matters. pp. 197-281.

Kearns, J. (2010). Swagger: Idealization, oppression and empowerment. Available online: http://stout.hampshire.edu/ jsk06/Swagger Jon_Kearns.pdf (Accessed 18 March 2011).

Keyes, C. 2002. Rap music and street consciousness. Urbana: University of Illinois Press.

Knobel, M. and C. Lankshear. 2008. Remix: The art and craft of endless hybridization. Journal of Adolescent \& Adult Literacy 52(1): 22-33.

Kreuger, A. 2012. Part II: Zef/poor white kitsch chique: Die Antwoord's comedy of degradation. Safundi 13(4): 399-408.

Lee, J. 2009a. Battlin' on the corner: Techniques for sustaining play. Social Problems 56(3): 578-598.

Lee, J. 2009b. Escaping embarrassment: Face-work in the rap cipher. Social Psychology Quarterly 72(4): 306-324.

Lessig, L. 2008. Remix: Making art and commerce thrive in the hybrid economy. London: Penguin.

Maher, J.C. 2010. Metroethnicities and metrolanguages. In N. Coupland (ed.) The handbook of language and globalization. Malden, MA: Wiley and Blackwell. pp. 575-591.

Marx, H. and V.C. Milton. 2011. Bastardised whiteness: 'Zef'-culture, Die Antwoord and the reconfiguration of contemporary Afrikaans identities. Social Identities 17(6): 723-745. 
Mesthrie, R. 2008. "I've been speaking Tsotsitaal all my life without knowing it": Towards a unified account of Tsotsitaals in South Africa. In M. Meyerhoff and N. Nagy (eds.) Social lives in language. New York: Benjamins. pp. 95-110.

Mesthrie, R. 2010. Sociolinguistics in South Africa: A critical overview of current research. In M.J. Ball (ed.) The Routledge handbook of sociolinguistics around the world. London: Routledge. pp. 187-202.

Morgan, M. 2009. The real hip-hop: Battling for knowledge, power and respect in the underground. Durham: Duke University Press.

Nkonyeni, N. 2007. Da struggle kontinues into the 21st century: Two decades of nation conscious rap in Cape Town. In S. Field, R. Meyer and F. Swanson (eds.) Imagining the city: Memories and cultures in Cape Town. Cape Town: HSRC Press. pp. 151-172.

Nuttall, S. 2009 Entanglement: Literary and cultural reflections on post-apartheid. Johannesburg: Wits University Press.

Orman, J. 2008. Language policy and nation-building in post-apartheid South Africa. Dordrecht: Springer Netherlands.

Osumare, H. 2007. The Africanist aesthetic in global hip-hop: How power moves. New York: Palgrave Macmillan.

Pennycook, A. and T. Mitchell. 2009. Hip-hop as dusty foot philosophy: Engaging locality. In H.S. Alim, A. Ibrahim and A. Pennycook (eds.) Global linguistic flows: Hip-hop cultures, youth identities and the politics of language. London: Routledge. pp. 25-42.

Perry, I. 2004. Prophets of the hood: The poetics and politics of hip hop. Durham, NC: Duke University Press.

Pietikäinen, S. and K. Kelly-Holmes (eds.) 2013. Multilingualism and the periphery. Oxford: Oxford University Press.

Potter, R. 1995. Spectacular vernaculars: Hip-hop and the politics of postmodernism. Albany: State University of New York Press.

Prah, K.K. (ed.) 2012. Mainstreaming Afrikaans: Regional varieties. Cape Town: CASAS.

Pritchard, G. 2009. Cultural imperialism, Americanisation and Cape Town hip-hop culture: A discussion piece. Social Dynamics 35(1): 51-55.

Rampton, B. 1999. Styling the other. Journal of Sociolinguistics 3(4): 421-427.

Rampton, B. 2006. Language in late modernity: Interaction in an urban school. New York: Cambridge University Press. 
Rose, T. 1994. Black noise: Rap music and black culture in contemporary America. Hanover: Wesleyan University Press.

Rose, T. 2008. Hip-hop wars: What we talk about when we talk about hip-hop - and why it matters. London: Basic Books.

Roth-Gordon, J. 2009. Conversational sampling, race trafficking, and the invocation of the Gueto in Brazilian hip-hop. In H.S. Alim, A. Ibrahim and A. Pennycook (eds.) Global linguistic flows: Hip-hop cultures, youth identities, and the politics of language. London: Routledge. pp. 63-78.

Sarkar, M. 2009. "Still reppin por mi gente": The transformative power of language mixing in Quebec hip-hop. In H.S. Alim, A. Ibrahim and A. Pennycook (eds.) Global linguistic flows: Hip-hop cultures, youth identities, and the politics of language. London: Routledge. pp. 139158.

Scott, D. 1999. Refashioning futures: Criticism after postcoloniality. Princeton, NJ: Princeton University Press.

Sharpley-Whiting, T.D. 2007. Pimps up, ho's down: Hip-hop's hold on young black women. New York: New York University Press.

Shohamy, E. 2006. Language policy: Hidden agendas and new approaches. London: Routledge.

Smitherman, G. 1977. Talkin and testifyin: The language of Black America. Detroit: Wayne State University Press.

Smitherman, G. 1997. "The chain remains the same": Communicative practices in the hip-hop nation. Journal of Black Studies 28(1): 3-25.

Smitherman, G. 2000. Black talk. Boston: Houghton Mifflin.

Terkourafi, M. 2010. The languages of global hip-hop. London: Continuum.

Warner, R. 2007. Battles over borders: Hip-hop and the politics and poetics of race and place in the new South Africa. Unpublished PhD dissertation. Toronto, Ontario: York University.

Watkins, L. 2000. Tracking the narrative: The poetics of identity in the rap music and hip-hop culture of Cape Town. Unpublished MA dissertation. Durban: South Africa.

Williams, Q.E. and C.J. Stroud. 2010. Performing rap ciphas in late-modern Cape Town: Extreme locality and multilingual citizenship. Afrika Focus 23(2): 39-59.

Williams, Q.E. and C.J. Stroud. 2013. Multilingualism in transformative spaces. Language Policy 12(4): 289-311. 